DOI: $10.31866 / 2410-1915.22 .2021 .235898$

UDC 7.071.1: [75.03(477):745.52(574)

\title{
WORK OF NIKOLAI TSIVCHINSKII: CONTRIBUTION OF THE BOYCHUK SCHOOL TO THE ART OF KAZAKH TAPESTRY
}

\author{
Sergali Suraganov ${ }^{1 a}$, Zubaida Suraganova ${ }^{2 b}$ \\ ${ }^{1}$ Senior Lecturer, \\ ORCID:0000-0003-0319-8115, sersuraganov@mail.ru, \\ ${ }^{2} \mathrm{PhD}$ in History, \\ ORCID: 0000-0001-9893-6461,suraganova_zk@mail.ru, \\ ${ }^{a}$ S. Seifullin Kazakh Agro-Technical University, \\ Zenis Ave., 62, Nur-Sultan, 010000, Kazakhstan, \\ ${ }^{b}$ Bozoq State Historical and Cultural Open-Air Museum \\ of the Ministry of Culture and Sports of the Republic of Kazakhstan, \\ 54 Tauelsizdik Ave., block 6, Nur-Sultan, 010000, Kazakhstan
}

\section{For citations:}

Suraganov, S., \& Suraganova, Z. (2021). Work of Nikolai Tsivchinskii: Contribution of the Boychuk School to the Art of Kazakh Tapestry. Culture and Arts in the Modern World, 22, 103-118. https://doi.org/10.31866/2410-1915.22.2021.235898.

The purpose of the research is to introduce the creative achievements of N. Tsivchinskii into scientific use in the context of the formation of the art school of the Ukrainian avant-garde of Mykhailo Boychuk. The study's objectives are to determine the origins of the formation of the muralist and arts and crafts master N. Tsivchinskii's work, his contribution to the shape of the history of the Kazakh professional tapestry. His work reflects the penetration and deep insight into the significance of traditional cultural identity, the Boychuk school's monumentalism inherent. One of the few surviving Boychukists who were scattered to the four corners of the earth by fate, N. Tsivchinskii developed the versatile skills, artistic language, and tradition of the Boychuk school also became one of the brightest figures in the Kazakh decorative and applied arts. The life path and work of N. Tsivchinskii reflect the most critical and tragic chapters of the country development thoroughly, which is no longer on the map. The research methods used are biographical, source-based, and historical. The methodological innovation of the research is the use of the biographical approach along with the historical one in the framework of the "new comparative history" as an effective tool for studying the artistic heritage of Kazakhstan and Ukraine in the Soviet era. The scientific novelty of the study is determined by the introduction of new information about the artist, whose work was only mentioned in the context of the Boychuk school scholars' activities, a significant part of whose followers were destroyed during the years of the Red Terror. Conclusions. The work of N. Tsivchinskii is considered in the context of the activity of the art school of M. Boychuk, where he became an arts and crafts master. In the 1930s, in Kazakhstan, N. Tsivchinskii continued the traditions of the Boychukists, became the founder

(C) Sergali Suraganov, 2021

(C) Zubaida Suraganova, 2021

The article was received by the editorial office: 09.03.2021 
of the first carpet cooperative craft society, which became a truly significant phenomenon in the history of the formation of professional decorative and applied art in the republic.

Keywords: Boychukists; tapestry; arts and crafts; Kovrovshitsa cooperative and trade craft society; Kazakhstan; Nikolai Tsivchinskii; Ukraine; Mykhailo Boychuk school; AllRussian Decorative Art Museum

\section{Introduction}

The relevance of the research is determined by the fact that many chapters of the history of the twentieth century and the history of art in the Soviet period remain insufficiently studied today. There is one chance only to restore the integrity of the picture of the events and processes of that time slowly, following Ariadne's clue - the few available facts. This chance was the "Ornamental Rhythms of the Eurasia. From Antiquity to Modernity” exhibition, held in 2018 at the site of the National Museum of the Republic of Kazakhstan (the Kazakh NM, Nur-Sultan) as part of "Heritage of the Commonwealth. Traditions for the Future" multi-year programme, carried out by the All-Russian Decorative Art Museum (the Russian DAM, Moscow) with the support of the Intergovernmental Foundation for Educational, Scientific and Cultural Cooperation of the CIS.

The exhibition was intended to use the museum collections of both museums: the Russian DAM and the Kazakh NM. In the spring of 2018, during the selection of photographs of museum objects from the Russian DAM collections, one of the exhibits, the Baiga tapestry, attracted the museum staff's attention immediately. It was hard to miss it. As follows from the information about the exhibit, the tapestry originated from Kazakhstan and dated back to 1939. The staff of the National Museum of the Republic of Kazakhstan, who was present at the selection, were solidly for exhibiting the tapestry at the exhibition in the capital of Kazakhstan. The tapestry became, in fact, the excellent reason to start a systematic study of the work of its author. Interest was aroused both by the plot depicted on the tapestry, Baiga (traditional Kazakh's horse tiltyards), and the "Stalindjk ul Konstitutsia çasasn" inscription - "All Hail the Great Stalin Constitution" in the upper border, as well as the history of its creation.

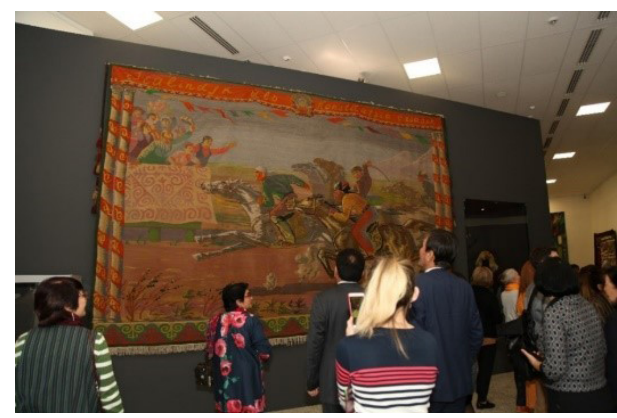

Figure 1. Baiga. N. Tsivchinskii. 1939. Tapestry, wool, cotton, metal threads, lint-free hand weaving. From the Russian DAM collection. At the "Ornamental Rhythms of the Eurasia. From Antiquity to Modernity" exhibition. Astana. National Museum of the Republic of Kazakhstan. 2018. Photo by S. Suraganov. 
Thanks to colleagues' professional behaviour and free will from the All-Russian Decorative Art Museum, this exhibit was again in Kazakhstan more than 80 years later. There is a reason that one of the creators of this exhibition L. Vvedenskaya called this fact the "hour of triumph" of this work.

So, the Baiga tapestry became a reason for studying the history of its creation and the biography of its authors.

During 2018-2019 we were working on the sources. Since the information about the central figure of our study was incomplete and fragmentary, any source was essential. From the guide to the Kazakh SSR pavilion at the AllUnion Agricultural Exhibition of 1939, the issue of the Ogonyok magazine for 1944, encyclopedias, his son's memoirs in the Vechernyaya Almaty newspaper (2008) and the "Art of Kazakhstan" textbook, brief data became available. In the Kazakhstan encyclopedia, it was indicated that Nikolai Tsivchinskii, the Soviet artist of monumental and decorative-applied art, the member of the Union of Artists of the USSR, the honoured worker of arts of the Kazakh SSR (1947), the author of the first Kazakhstan tapestries, was born on December 13, 1905, in St. Petersburg and died on February 24, 1985, in Almaty, studied at the Mezhyhiria Ukrainian Technological Institute of Ceramics and Glass (1927), worked at the Budyansky Faience Factory in the Kharkiv region (1927-1929), carpet and tapestry factory in Almaty (1937-1941, 1945).

Unfortunately, in Kazakhstan Art Studies, the name of N. Tsivchinskii is found from time to time only in connection with his work in the Kovrovschitsa cooperative craft society. Information about this is present in the survey works devoted to the history of decorative and applied art, joint industry and architecture (works by E. G. Malinovskaya, M. F. Mukanov, M. Sh. Suleimenov, A. Zh. Nurgaliev, S. A. Shklyaeva, etc.).

The personality of N. Tsivchinskii, thanks to his two articles published in the scientific publications "Folk Art" (Tsivchinskii, 1939) and "Izvestiya AN Kazakh SSR" in the series "Art Studies" (Tsivchinskii, 1950), testify to his research potential, which, unfortunately, remained untapped (Viner, 1969, p. 7). Writing these works indicates both the artist and art expert maturity of $\mathrm{N}$. Tsivchinskii, who can generalise and evaluate the processes in art. The image of the 20-metre tapestry "Amangeldy, Kazakh National Hero" is completed by the article "Kazakh Tapestry", published in 1939. The article's manuscript is kept in the Russian State Archive of Literature and Art (Tsivchinskii, 1936-1939).

Thus, some idea of the artist's personality and his work was obtained. But it still did not clarify the central question of how and under whose influence $\mathrm{N}$. Tsivchinskii was formed as an artist.

As a result, a report was prepared on the topic "Kovrovshitsa Almaty cooperative craft society as an example of a successful creative union of folk and professional arts", which was presented at the IV Conference of "the Heritage of the Commonwealth. Traditions for the Future" programme, held on October 28 - November 1, 2019, in the capital of Armenia - Yerevan, at the House-Museum of Aram Khachaturian. After the speech, one of the participants of the conference, L. D. Sokoliuk, professor of the Kharkiv State Academy of Design and Fine Arts, DSc of Art Studies, who has been fruitfully studying 
Ukrainian art for many years in the 20s-the 30 s of the $20^{\text {th }}$ century, pointed out the close connection of the author of the Baiga tapestry N. Tsivchinskii with the well-known school of M Boychuk in Ukraine.

Meeting with Lyudmila Sokoliuk, whose works provide a comprehensive analysis of the work of Mykhailo Boychuk and his followers: the first wave Boychukists and the second - Young Boychukists, finally revealed the most critical information about the history of the formation of $\mathrm{N}$. Tsivchinskii as an artist (Sokoliuk, 2014).

As the analysis of recent studies and publications on the history of the school of M. Boychuk but the study by L. Sokoliuk shows, there is no reference to N. Tsivchinskii being the school's representative. The study of such a bright and original artistic phenomenon of Ukraine as Boychukism, thanks to the research of recent years, allows us to restore not only its history but also the list of followers and graduates of the school of M. Boychuk. It is no accident that in one of the works dedicated to the Boychukist I. Trehub, it is noted that "the circle of students of M. Boychuk and artists who experienced his influence is not limited to "the names of three artists, which are given in the monograph "The School of Mikhail Boychuk. Thirty-Seven Names" by Yaroslav Kravchenko, the son of Boychukist Ohrim Kravchenko. And "it means that it is too early to put an end to the study of the topic ..." - the author of the article I. Zhdanko (2011) summarises rightly. Being with the view, within this article, we will try to consider the artist's resume of the Boychukian Nikolai Tsivchinskii, whose name is totally linked with the history of the formation of the professional art of tapestry in Kazakhstan.

\section{Purpose of the article}

The purpose of the article is to introduce into scientific use the creative achievements of $\mathrm{N}$. Tsivchinskii, filling the chapters of the history of the M. Boychuk school of the Ukrainian avant-garde with the artist's resume of its representative - the Kazakh artist N. Tsivchinskii.

The L. D. Sokoliuk's expert opinion clarified an important missing link in the artist's creative destiny, which could restore the integrity of the biography of N. Tsivchinskii, helped to answer the question about the quality of professional training of the tapestry author, the founder and first artistic director of the Kovrovshitsa Almaty cooperative craft society, which laid the foundation for a fruitful union of artists and folk craftspeople. An additional impulse was received for further study of the life and work of the author of the Baiga tapestry.

As follows from the Kazakhstan Encyclopedia, in 1927, N. Tsivchinskii graduated from the Mezhyhiria Ceramic Technical College with a degree in Ceramic Artist-Architect. The Mezhyhiria Ceramic Technical College, since 1922, was headed by V. Sedliar (1899-1937) - a student and joiners of M. Boychuk, who graduated from his workshop of monumental art at the Ukrainian Academy of Arts ("Neizvestnye stranitsy", 2009, p. 125). According to the research by L. Sokoliuk in Mezhyhiria, the College's skeleton teaching staff was formed 
under the leadership of V. Sedliar in 1928 (Sokoliuk, 2004, p. 22). In V. Sedliar's idea, Mezhyhiria Ceramic Technical College was to be transformed into a scientific and educational, industrial and cultural community, in which, along with an academic cluster, a research institute, as well as a pilot plant and a museum of ceramics would work. The museum's main task was to form collections of artistic items made of ceramics: porcelain, faience, majolica, tiles, stone mass, and terracotta. But it wasn't to be. In 1931, the Mezhyhiria Ceramic Technical College was closed (Sokoliuk, 2004, p. 23).

Thus, thanks to the research of L.D. Sokoliuk, it became clear that $\mathrm{N}$. Tsivchinskii, likely, got the Boychukists, studying at the Mezhyhiria Ceramic Technical College.

Since N. V. Tsivchinskii headed a carpet cooperative craft society in Kazakhstan and worked in it as a mature, well-formed artist, the question arose: how was he initiated into the intricacies of this craft? The answer was also received after reviewing the work of L. D. Sokoliuk. After graduating from the Mezhyhiria Ceramic Technical College, the young artist worked in Kyiv. And here, apparently, he continued to communicate and work with a student of the first graduating class of the workshop of M. Boychuk - S. Kolos who developed the principles of Boychukism in artistic textiles. Since 1925, S. Kolos worked among the teachers of the Kyiv Art Institute, heading the department of art textiles at the Faculty of Painting. The main principle of the department was the strong interrelation between artistic and technological programme subjects, where scientific and theoretical work was combined with practice on weaving looms and at textile enterprises. The basis of classroom training was studying world art and Ukrainian arts and crafts (Sokoliuk, 2004, p. 23). It is for this reason that L. D. Sokoliuk emphasises that the most important contribution to the development of Ukrainian decorative and applied art and the merit of Boychukism consists in introducing young artists to the art of "great ideas embodied in an adequate monumental form, on the one hand, national in nature, on the other related to the search for a new plastic language in the world art culture of that period" (Sokoliuk, 2004, p. 30).

In 1936, N. Tsivchinskii participated in the preparation of an exhibition of Ukrainian folk art. Its exhibitors, to help the folk craftswomen-weavers get closer to the art of socialist realism, invited professional painters and graphic artists to make tapestries, including M. Boychuk and his students, the most prepared for working in this art form. Among them, "M. Tsivchynskyi" (M. from Mykola - Nikolai in Russian) is also mentioned (Sokoliuk, 2004, p. 26).

Perhaps this was the last joint work of M. Boychuk with his students. The negative trends that emerged in the early 1930s as the closure of the Mezhyhiria Ceramic Technical College in 1931 and then the declaration of the principles of Boychukism, which developed at the textile department of the painting faculty of the Kyiv Art Institute, as inconsistent with the state art policy - as a result, led to dissociation of various art forms. This was a blow to the integrity of M. Boychuk's artistic system (Sokoliuk, 2004, pp. 25-26). Today, scientists regret to note that many factors of that time did not allow Boychukism to enter the wide world scene. The tragedy is that the Mexican "muralism", typologically 
close to the school of "Ukrainian monumentalism", was supported by the state art policy, which eventually gave significant results for the entire world of artistic creativity. Under totalitarianism, the Boychukists were provided with appropriate orders, but everything they did was exterminated barbarously (Sokoliuk, 2004, p. 30).

Essential events also take place in the fate of N. Tsivchinskii. In Kyiv, as his son Alexander recalls, Nikolai Tsivchinskii met with the circus artist Olga Barova and got married to her. In the pre-war period, the Barova sisters, the tightrope walkers, were trendy in Ukraine. Due to an injury, multiple fractures of both legs during the performance, Olga Barova had to give up her career as an artist. Unfortunately, the sources give different dates for the same events. And yet, apparently, no later than 1936, Nikolai Tsivchinskii moved with his pregnant wife, her sister, brother and mother to Almaty, where his son Alexander was soon born ("Master krupnykh form", 2008, p. 27). In an interview, the artist's son clarifies that the reason for moving to Almaty was the repression: "In Kyiv, the so-called "artists proceeding" was initiated" ("Master krupnykh form", 2008, p. 27).

Despite the physical destruction of most of the followers of the school of M. Boychuk, its works (Zemlyanaya, 2009b, p. 25), some of the students survived. The school of M. Boychuk, as the researchers note, was international in keeping with the temper of the times. Among its representatives is the German artist K. Hiller (Zemlyanaya, 2008, p. 227), as well as those of the Boychukists who escaped repression: O. T. Pavlenko (1895-1991) and N. V. Tsivchinskii (1905-1985), E. Antonovych (emigrated to Canada, founded an art school in Winnipeg), R. Lisovsky (taught in Prague), N. Azovsky (worked as a theatre artist in European and American cities), Gordynsky and M. Osinchuk (continued the work of muralists in the United States) (Zemlyanaya, 2009a, p. 209). The assessment of T. N. Zemlyanaya, who emphasised that "Boychukism" has "revived" in the diaspora, is very accurate in this regard (Zemlyanaya, 2009a, p. 209). The surviving Boychukists created the foundation for the birth of the phenomenon of the Young Boychukists. Students of the students are the artist from Kryvyi Rih, G. Sinitsa (1908-1996), a student of I. Padalka, the St. Petersburg artist I. N. Zisman (1914-2004), a student of E. Shekhtman, whom M. Boychuk singled out as an exceptionally gifted artist (Zemlyanaya, 2009b, p. 36). Apparently, as L. D. Sokoliuk emphasised in a personal conversation, since O. Pavlenko worked and taught in Moscow, she escaped repression and remained alive, which allowed her to make a significant contribution to the development of Soviet decorative art.

Rewarding that the Boychukians, having absorbed the principles of its work, continued his work, relying on the knowledge and experience that they gained from their teacher. One of M. Boychuk's workshop principles was collectivism in the process of work (Zemlyanaya, 2009b, p. 29).

Like other Boychukists, N. V. Tsivchinskii worked in various genres of decorative and fine art. As a prominent representative of the school, where "they worked on the creation of synthetic art ensembles of painting, sculpture, architecture, decorative and applied art" (Zemlyanaya, 2014, p. 496) and where 
they trained universal artists, N. Tsivchinskii also acquired the qualities of an organiser, which was helpful to him in Kazakhstan, where he was destined to become the founder of the art of tapestry.

So it became clear by what circumstances N. V. Tsivchinskii, a well-formed professional artist, a representative of the school of M. Boychuk, had proven to be in Kazakhstan. The training he received among the Boychukists allowed him to become the founder and head of the Kovrovshitsa Almaty cooperative craft society of the Kazprom Council in 1936 (Kozybaev, 1983, pp. 303-304; Tsivchinskii, 1939, p. 41). In the cooperative craft society, he created sketches for "the first Kazakh tapestries ("Harvest Festival”, "Amangeldy, Kazakh National Hero", 1937; "Kolkhoz feasting”, 1939; "Break into the Mannerheim line by the Red Army", 1940), taught craftswomen weaving techniques with visual compositions" (Shklyaeva, 2015, p. 170). It seems that it was the experience gained at the school of M. Boychuk that allowed him to cope with this difficult task. Since its creation, the cooperative craft society had been producing carpets and producing woven tapestries (Nurgaliev, 2016, p. 112). "There are the plot compositions with the specific techniques of realistic light-and-dark easel painting of socialist realism were complemented by carpet ornamental borders" (Shklyaeva, 2010, p. 12).

Here is how he describes his work in the Kovrovshitsa cooperative craft society: "It is interesting to note the different attitude to the new technique and drawing among the masters - Kazakh, Uighur, Russian and Dungan women. Some Kazakh women used to weave ornamental "palas" in the past... In the Almaty cooperative craft society, there are only two weavers who know the old carpet-weaving technique... Young people were the fastest to master the new carpet-weaving technique" (Tsivchinskii, 1939, p. 41). In his article, the artist names the masters, among whom is Siya Dzhyunusova, Togombaeva, Suslikova, Vyskubova, Ryazantseva, Shakhovtseva; the names of Dungan women, about whose embroidery skills he celebrates, unfortunately, they are not named (Tsivchinsky, 1939, p. 41). In the chapter of the textbook "Art of Kazakhstan" devoted to an applied art, the authors cite another name of the Kazakh folk craftswoman - R. Baymukhamedova, who worked in the cooperative craft society (Kishkashbaev \& Shklyaeva, 2006, p. 202). According to the researchers, handkerchiefs were also embroidered and painted in Kovrovshitsa (Shklyaeva, 2010, p. 12). According to the famous Kazakh artist Vadim Sidorkin, his mother - an actress and an outstanding painter Gulfairus Ismailova worked during the war in the cooperative craft society of carpet makers, where she made murals (Vykhodchenko, 2015).

Having headed the experimental workshop and being both a leader and an artist, N. Tsivchinskii continued the traditions that took roots from the school of M. Boychuk in Kazakhstan. As a true Boychukist, N. Tsivchinskii, respecting folk traditions, "did not refer to the archaic, but created a new art based on the most ancient powerful achievements of monumentalism, chaste in its aesthetic tasks and social ideals" (Zemlyanaya, 2009a, pp. 202-203), tried to show the ethnic face of the people, their character and spiritual qualities (Zemlyanaya, 2013a, p. 82). 
It is known that the tapestries of the cooperative craft society, N. Tsivchinskii drew sketches for, were successfully exhibited in Prague, Beijing, Warsaw (Shklyaeva, 2010, p. 12), Moscow, Paris, New York (Shklyaeva, 2015, p. 170). Tapestries with images of Stalin, Lenin, Stanislavsky, thematic tapestries "Meeting of the leading agricultural workers of the Kazakh SSR with the leaders of the party and government", "Kolhoz Feasting" were exhibited at the All-Union Agricultural Exhibition in Moscow (1940) (Kolpakchi, 1944, p. 11). The article "Kazakh Tapestry" provides the name of the Harvest Festival tapestry, which was of 20 square meters (Tsivchinskii, 1939, p. 41). The tapestry was presented to Leningrad (Shklyaeva, 2015, p. 170). There are two known tapestries on military themes related to the pre-war events in the USSR - "The Break into the Mannerheim Line" and "The Liberation of the Fraternal Peoples of Western Ukraine by the Red Army" (Kolpakchi, 1944, p. 11). As noted in the Ogonyok magazine, "N. Tsivchinskii is one of the most earnest initiators of creating a new form of fabric art as a lint-free painting carpet in Kazakhstan. The artist began to implement his initiative on the basis of the highly developed technique of the ancient palace in 1937" (Kolpakchi, 1944, p. 11).

According to art critics, in his works, N. Tsivchinskii "addresses significant themes from the history and modern life of the republic, solving compositions in terms of large decorative generalisations. His works are characterised by clarity of plastic design, rhythmic construction of drawing and colour" (Nurmukhammedov, 2012, p. 159).

Kazakhstan art critic E. Malinovskaya is the author of a "Physical Culture Parade" huge tapestry (N. Tsivchinskii's article indicates 18 sq. metres), which was exhibited at the World Exhibition in New York. This work received the Grand Prix in 1939 (Malinovskaya, 2016, p. 367). The tapestry "demonstrated changes in the perception of the nation's culture through the achievements of modernity by plot and unconventional technology" (Malinovskaya, 2016, p. 367). But in the guidebook of the All-Union Agricultural Exhibition in the pavilion of the Kazakh SSR in 1940, under the drawing with the image of the "Physical Fitness Culture Parade in Almaty" tapestry, the name of the artist A. Rittikh is indicated (Batsanov, 1940, p. 73). In the mentioned article "Kazakh Tapestry" by N. Tsivchinskii, the work is unowned (Tsivchinskii, 1939, p. 41).

In the year of the beginning of the war, in 1941, the cooperative craft society went defunct. In the spring of 1942, Nikolai Tsivchinskii was drafted into the Red Army. He joined the Battle of Stalingrad as a mortarman. In the autumn of the same year, he sustained leg injuries ("Master krupnykh form", 2008, p. 27). After the injury, he was treated in Gorky. Apparently, after the treatment, the artist painted the auditorium of the Gorky House of the Red Army (later the House of Officers). "Four of his huge canvases are dedicated to the major events of the Great Patriotic War: the historical battle for Moscow ("Panfilov's 28 Men"), the heroic battle for Sevastopol ("We will be back later"), the defeat of Hitler's troops at Stalingrad and the crossing of the Dniepro River by Soviet soldiers" (Kolpakchi, 1944, p. 11; "Master krupnykh form", 2008, p. 27). The work entitled "We be back later" accompanies the text of an article in the Ogonyok magazine, 1944. 
According to the archival documents, the cooperative craft society resumed its activities in the second half of 1944 in trying circumstances: without heating and equipment, with a lack of carpet makers (Shklyaeva, 2015, p. 174).

Later, the workshop was equipped with "three new vertical loops" (Nurgaliev, 2016, p. 112). And, as noted in the work of N. Nurgaliev, the first work, which eight weavers weaved, "was called "The Feat of Panfilov's 28 Men”. Popular paintings from the cycle "Hero-Cities": "The Defense of Stalingrad", "The Defense of Leningrad”, “The Defense of Sevastopol” (Nurgaliev, 2016, p. 112). Therefore, $\mathrm{N}$. Tsivchinskii prepared sketches, repeating the paintings made earlier in the Gorky House of the Red Army. According to the memoirs of his son, the artist from the front "brought a lot of drawings: soldiers resting in the trenches, killed on the battlefield, and others... After returning, he was given a large room, 20 metres; before that they located in a basement. One wall had always been used for sketches and tapestries" ("Master krupnykh form", 2008, p. 27).

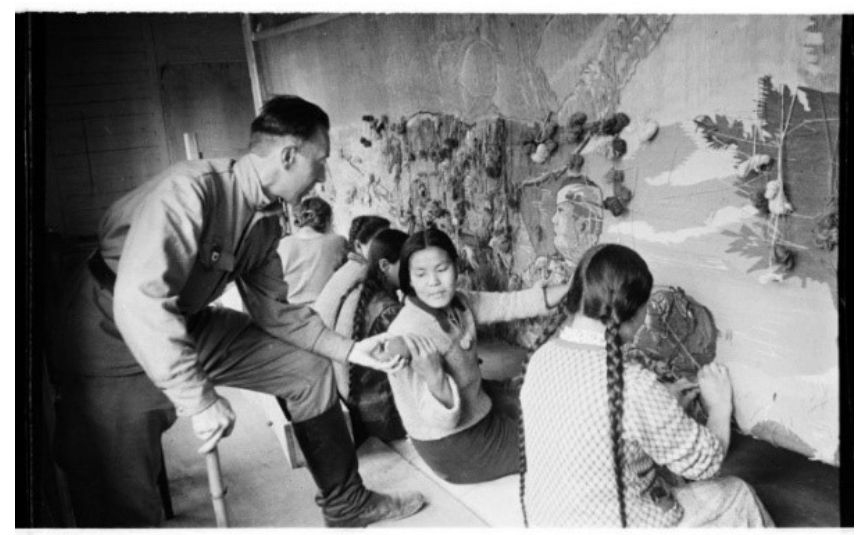

Figure 2. In the tapestry workshop. The artist N. Tsivchinskii is running the work in the workshop. Photo by Semyon Fridlyanda. The 1950s (?) (Kazakhstan in the photos by Semyon Fridlyand).

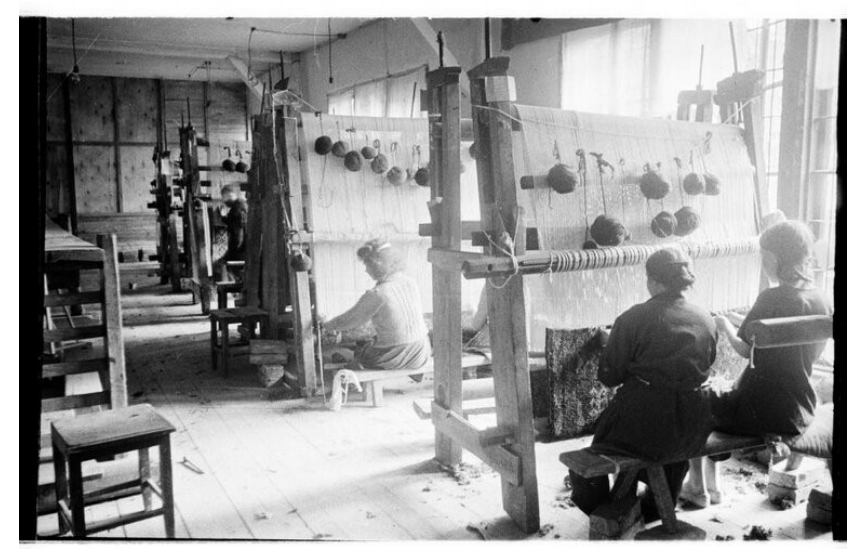

Figure 3. In the weaving department of the tapestry workshop. Photo by Semyon Fridlyanda. The 1950s (?) (Kazakhstan in the photos by Semyon Fridlyand). 
In the post-war period, the artist continued to work on tapestries. The largest of them "On Red Square" (70 sq. m.) was created in 1949 and decorated the foyer of the "Gornyak" Palace of Culture in Karaganda ("Master krupnykh form", 2008, p. 27). The work "Amangeldy, Kazakh National Hero" (20 sq. m.) was presented to the Bolshoi Theatre of the USSR on the date of the $175^{\text {th }}$ anniversary ("Master krupnykh form", 2008, p. 27).

The tapestries of the "Kovrovshitsa" cooperative craft society are characterised, as in general for the decorative and applied art of Kazakhstan in the first third of the twentieth century, by three essential features identified by the art critic S. A. Shklyaeva: "imperative", "hereditary" and "interpretative" traditionalisms (Shklyaeva, 2010, p. 25). "Imperative" traditionalism in the mainstream of totalitarian art was distinguished by the presence of Soviet symbols, letter elements, which were present in the above-mentioned Baiga tapestry, where there is an inscription - slogan in Latin. "Hereditary" traditionalism was based on the continuity in the technique and decor of carpet making of the "Kovrovshitsa" cooperative craft society, which was manifested in the involvement of folk craftsmen. "Interpretive" traditionalism was expressed in combining the new with the tradition (Shklyaeva, 2010, p. 25). The principles of "hereditary" traditionalism were instilled in N. Tsivchinsky at his alma mater, where her mastermind and teacher - M. Boychuk "instructed his students not to forget about their national identity" (Zemlyanaya, 2013b, p. 190).

It is known that the artist also participated in the facade decorating of the Almaty Hotel (scene from the epic "Enlik-Kebek"), the bas-relief on the facade of the Abay State Academic Opera and Ballet Theatre. He also decorated the Palace of Metallurgists in Ust-Kamenogorsk (1957), the Palace of Culture of Builders in Balkhash, the Sholpan Cafe in Almaty (1961).

The most significant in the decorative design was the works created by N. Tsivchinskii in collaboration with M. Kenbaev in Almaty: mosaics "Kokpar" (the name of the national equestrian game), "Koblandy" (the name of the epic hero-bogatyr) in the Almaty Restaurant(1963), in the Ainabulak Cafe (1966), "Girl with a Souvenir" and "Kazakh folk crafts" sgraffito for the Kazakhstan Store (1972), "Kazakh National Costume" painting and the "Dressing the Bride" stained glass window in the House of Models (1969), the decoration of the Wedding Palace (1971); in Dzhambul, there was the "Kozy Korpesh Bayan sulu" painting (the heroes of the epic work, one version of which was recorded at the time by A. Pushkin) in the Vostok Restaurant (1968) and others (Kozybaev, 1983, p. 94, p. 221).

The "Soviet Poster" website indicates that the author of the poster "FiveYear Plan's Victory - a Blow to Capitalism!” is N. Tsivchinskii (Tsivchinskii, 1931). On the Internet resource "Soviet Political Poster. The Collection of Sergo Grigoryan", his authorship is confirmed. The Internet presents his painting work "The Girl with the Ball" also, painted by him in the pre-war 1930s. He tried himself both as a painter and an artist of applied art (Tsivchinskii, 1930). The latter became his life's work. 


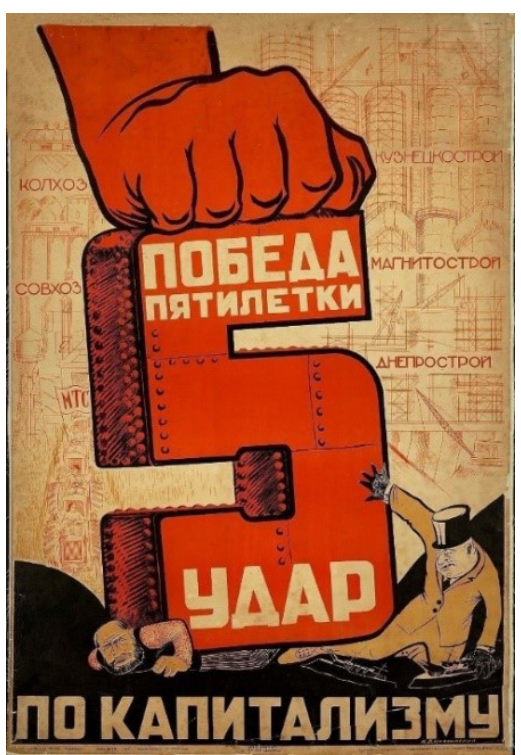

Figure 4. Five-Year Plan's Victory a Blow to Capitalism! Tsivchinskii N. V. 1931 (http://tramvaiiskusstv.ru)

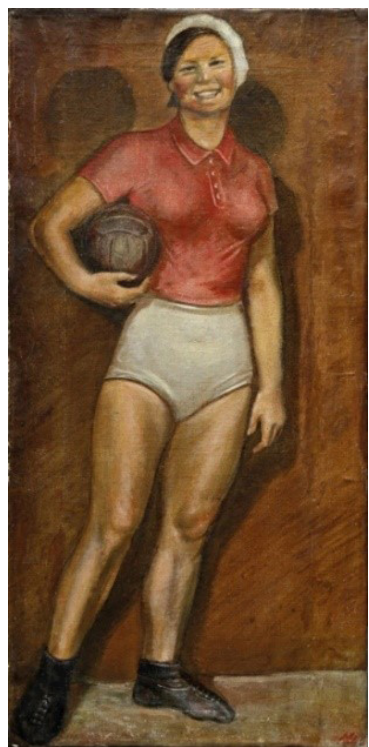

Figure 5. The Girl with the Ball. Tsivchinskii N. V. Oil on Canvas. The 1930s. $73.5 \times 36$ (http://bonart.kz).

Boychukist by nature, N. Tsivchinskii remained true to the creative principle of the Boychuk school, who "together with his students ... created Ukrainian art in almost all its forms and genres” (Zemlyanaya, 2009a, p. 209), formed with them "a unique style of art - a synthetic style, monumental in the form and nature of creative thinking” (Zemlyanaya, 2009b, pp. 15-16).

\section{Conclusions}

Thus, the personality of a gifted and highly professional applied artist, researcher and organiser of craft production appeared before us. The origins of his work were got in Ukraine, in the Boychuk school, recognised today as a unique phenomenon in the Ukrainian art of the twentieth century and Soviet decorative and applied art in general.

Considering the works of N. Tsivchinskii, we would like to note that he largely remained faithful in his work to the deep connection inherent in the Boychukists with the sacred traditions of folk art, which L. Sokoliuk noted. This is especially noticeable in his Baiga tapestry, the decorative design of architectural structures throughout Kazakhstan. The Baiga tapestry was exhibited in 1939. In a very short period (1-1,5 years) of stay in Kazakhstan, the artist caught the importance of horse racing in the culture of the Kazakhs - the rider-people. Equestrian lists were traditionally present and are now being revived in the programmes of the Kazakhs' life cycle rituals, accompanied by feasts on the occasion of the birth of their sons, wedding and funeral feasts (as). In Soviet times, equestrian competitions became an indispensable element of harvest festivals, Shepherd's Day, etc. 
N. Tsivchinskii escaped the tragic fate of his colleagues. Saving his family, he went to distant Kazakhstan, where he continued to develop on the chosen path of art.

The legacy of N. Tsivchinskii is carefully preserved in Kazakhstan. To the $70^{\text {th }}$ anniversary of the Victory, the graphic and watercolour works of the artist, made by him in 1942 ("The Head of a Murdered German", "A Skeleton in a Ravine", "A Captured German"), were restored from the funds of the Central State Museum of the Republic of Kazakhstan (Almaty).

Thus, the twists and turns of artist's fates from Ukraine, who happened to be in Kazakhstan due to circumstances, and folk craftsmen of different ethnic origins boosted not only to create a successful production but also to the birth and development of a new type of woven tapestry applied art.

At the end of the article, I would like to thank the incredible artist and author of many successful exhibition projects, known for her collections and performances in the ethnographic style, L. Vvedenskaya, which helped the authors in finding an article by N. Tsivchinskii in the "Folk Art" magazine, 1939. I would also like to express my great gratitude to the Kharkiv State Academy of Design and Art professor, DSc of Art Studies, art historian L. Sokoliuk. Thanks to her, the origins of the creative environment in which the artistic taste and style of $\mathrm{N}$. Tsivchinskii were formed became clear. We also express our gratitude to the Russian DAM's management and staff E. Titova, G. Andreeva, A. Gilodo, M. Kirsanova and others for organising the programme, which makes such a significant contribution to the development of cooperation between the CIS countries, creating a favourable environment for a broad humanitarian dialogue between representatives of different states, ethnic and professional communities, contributing to the search and resolution of issues of the development of the art of the $21^{\text {st }}$ century.

\section{References}

Batsanov, N. S. (Comp.). (1940). Pavil'on "Kazakhskaya SSR": putevoditel' [Pavilion "Kazakh SSR": a Guide]. Ob"edinenie gosudarstvennykh knizhno-zhurnal'nykh izdatel'stv ; Sel'khozgiz [in Russian].

Kishkashbaev, T. A., \& Shklyaeva, S.A. (2006). Prikladnoe iskusstvo [Applied Art]. In A. S. Galimzhanova, M. B. Glaudinova, T. A. Kishkashbaev, S. A. Shklyaeva, K. K. Murataev， G. Sh. Eleukenova， \& B. K. Barmankulova (Comps.), Istoriya iskusstv Kazakhstana [History of Arts of Kazakhstan] (pp. 202-210). IzdatMarket [in Russian].

Kolpakchi, L. (1944). Khudozhnik-voin [Warrior Artist]. Ogonek, 17-18, 11 [in Russian]. Kozybaev, M. K. (Ed.). (1983). Alma-Ata. Entsiklopediya [Almaty. Encyclopedia]. Glavnaya redaktsiya kazakhskoi sovetskoi entsiklopedii [in Russian].

Lord Fame. (2014, July 9). Kazakhstan na snimkakh Semena Fridlyanda [Kazakhstan in the Pictures of Semyon Fridlyand]. Mir aviatsii i puteshestvii Vyacheslava Firsova. http://firsov.kz/?p=768 [in Russian].

Malinovskaya, E. G. (2016). Istoriko-kul'turnoe nasledie arkhitektury natsional'nogo stilya Kazakhstana [Historical and cultural heritage of architecture of national 
Kazakhstan style]. Culture and civilisation, 6, 360-374. http://publishing-vak.ru/ file/archive-culture-2016-6/34-malinovskaya.pdf [in Russian].

Master krupnykh form [Master of Large Forms]. (2008, September 11). Vechernii Almaty, 111, p. 27 [in Russian].

Neizvestnye stranitsy ukrainskogo avangarda [Unknown Pages of the Ukrainian AvantGarde]. (2009). ACADEMIA, 4, 125 [in Russian].

Nurgaliev, A. Zh. (2016). Kooperativnaya promyshlennost' Kazakhstana v gody Velikoi Otechestvennoi voiny (1941-1945) [Cooperative Industry of Kazakhstan during the Great Patriotic War (1941-1945)] [PhD Dissertation]. Chelyabinsk State University [in Russian].

Nurmukhammedov, N-B. (2012). Iskusstvo Kazakhstana. Klassicheskie issledovaniya [Art of Kazakhstan. Classic Studies] (Vol. 10, pp. 115-186). Odebiet əlemi [in Russian].

Shklyaeva, S. A. (2010). Problemy razvitiya prikladnogo iskusstva Kazakhstana: Sovetskaya epokha-period Nezavisimosti (XX-nachalo XXI veka) [Problems of the Development of Applied Arts in Kazakhstan: Soviet Era - the Period of Independence (the $20^{\text {th }}$ - Early $21^{\text {st }}$ Century)] [Abstract of PhD Dissertation]. Kazakhskaya Golovnaya Arkhitekturno-Stroitel'naya akademiya [in Russian].

Shklyaeva, S. A. (2015). Nekotorye aspekty deyatel'nosti artelei v Kazakhstane perioda Velikoi Otechestvennoi voiny [Some Aspects of the Activities of Artels in Kazakhstan During the Great Patriotic War]. In S. Gracheva (Ed.), Voina, beda, mechta i yunost'! Iskusstvo i voina [War, Trouble, Dream and Youth! Art and War], Proceedings of the International Scientific and Practical Conference (pp. 168-176). BuksMArt [in Russian].

Sokoliuk, L. D. (2004). Mykhailo Boichuk ta yoho kontseptsiia rozvytku ukrainskoho mystetstva (persha tretyna XX stolittia) [Mykhailo Boichuk and His Concept of Development of Ukrainian Art (the First Third of the 20th Century)] [Abstract of DSc Dissertation]. Kharkiv State Academy of Design and Arts [in Ukrainian].

Sokoliuk, L. D. (2014). Mykhailo Boichuk ta yoho shkola [Mykhailo Boichuk and His School]. O. O. Savchuk Publishing House [in Ukrainian].

Tsivchinskii Nikolai Vladimirovich (1905-1985). (n.d.). Tramvai iskusstv. Retrieved July 12，2019， from http://tramvaiiskusstv.ru/plakat/spisok-khudozhnikov/ item/712-tsivchinskij-nikolaj-vladimirovich-1905-1988.html [in Russian].

Tsivchinskii Nikolai Vladimirovich. (2017, April 17). In Kazakhstanskaya entsiklopediya [Kazakhstan Encyclopedia]. Retrieved July 12, 2019, from http://ru.encyclopedia. kz/index.php/Tsivchinskii,_Nikolai_Vladimirovich [in Russian].

Tsivchinskii, N. V. (1930). Devushka s myachom. Kholst, maslo, 1930-e gody, 73,5×36 [The Girl with the Ball. Oil on Canvas, 1930s, 73.5×36] [Painting]. (Lot 76). BonArt. Retrieved May 14, 2019, from http://bonart.kz/devushka-s-myachom.html [in Russian].

Tsivchinskii, N. V. (1931). Pobeda pyatiletki udar po kapitalizmu! [The Victory of the Five-Year Plan is a Blow to Capitalism!]. Soviet Political Poster the Sergo Grigorian Collection. Retrieved August 26, 2019, from http://redavantgarde.com/ collection/show-collection/2177-the-victory-of-the-five-year-plan-is-a-crash-ofcapitalism-.html [in Russian].

Tsivchinskii, N. V. (1936-1939). Kazakhskii gobelen. Rukopis' stat'i [Kazakh Tapestry. Manuscript of the Article]. (Fund 673 Redaktsiya zhurnala "Narodnoe tvorchestvo", 
Inventory 1, File 613). The Russian State Archive of Literature and Arts, Moscow [in Russian].

Tsivchinskii, N. V. (1939). Kazakhskii gobelen [Kazakh Tapestry]. Narodnoe tvorchestvo, 4, 41 [in Russian].

Tsivchinskii, N. V.(1950). Kazakhskii sovetskii gobelen [Kazakh Soviet Tapestry]. Izvestiya Akademii nauk Kazakhskoi SSR. Seriya iskusstvovedeniya, 1, 84-89 [in Russian].

Viner, E. (Comp.). (1969). Kovry i tkatskoe proizvodstvo narodov Srednei Azii, Kavkaza i Zakavkaz'ya [Carpets and Weaving of the Peoples of Central Asia, the Caucasus and Transcaucasia]. Gosudarstvennaya publichnaya biblioteka imeni M. E. SaltykovaShchedrina [in Russian].

Vykhodchenko, L. (2015, January 03). Ona byla prekrasnoi mater'yu. Interv'yu s synom G. Ismailovoi [She Was a Wonderful Mother. Interview with the Son of G. Ismailova]. Qazaqstan Tarihy. Retrieved April 26, 2019, from https://e-history.kz/ru/ publications/view/880 [in Russian].

Zemlyanaya, T. N. (2008). Ukrainskaya monumental'naya zhivopis'. Stanovlenie shkoly M. L. Boichuka [Ukrainian Monumental Painting. Formation of M. L. Boychuk's School]. Izvestiya SFedU. Engineering Sciences, 1(78), 225-228 [in Russian].

Zemlyanaya, T. N. (2009a). Khristianskie obrazy v tvorchestve M. L. Boichuka (18821937) [Christian Images in the Works of M. L. Boichuk (1882-1937)]. Peterburgskie iskusstvovedcheskie tetradi, 14, 200-212 [in Russian].

Zemlyanaya, T. N. (2009b). Monumental'naya zhivopis' M. L. Boichuka i ego shkola [M. L. Boichuk's Monumental Painting and His School] [Abstract of PhD Dissertation]. Saint-Petersburg University of the Humanities and Social Sciences [in Russian].

Zemlyanaya, T. N.(2013a). Osobennosti obraznogo i stilisticheskogo stroya proizvedenii M. Boichuka i ego shkoly [Features of the Figurative and Stylistic Structure of the Works of M. Boychuk and His School]. Nauchnoe mnenie, 10, 77-83 [in Russian].

Zemlyanaya, T. N. (2013b). Ukrainskii avangard - utrachennaya stranitsa mirovogo iskusstva? (Monumental'naya zhivopis' M. L. Boichuka i ego shkola) [Ukrainian Avant-Garde - a Lost Page of World Art? (Monumental Painting by M. L. Boychuk and His School)]. Problems of Modern Science and Education, 3(17), 182-195. https:// cyberleninka.ru/article/n/ukrainskiy-avangard-utrachennaya-stanitsa-mirovogoiskusstva-monumentalnaya-zhivopis-m-l-boychuka-i-ego-shkola [in Russian].

Zemlyanaya, T. N. (2014). Aktual'nost' i vazhnost' dostizhenii "Shkoly M. L. Boichuka" kak primer novogo original'nogo yavleniya $\mathrm{v}$ monumental'nom iskusstve XX veka [The Relevance and Importance of the Achievements of the "School of M. Boychuk" as an Example of a New Original Phenomenon in the Monumental Art of the $20^{\text {th }}$ Century]. Problemy rozvytku miskoho seredovyshcha, 1, 493-499 [in Russian].

Zhdanko, I. (2011). Ocherk zhizni i tvorchestva khudozhnika Ivana Triguba [Essay on the Life and Work of the Artist Ivan Trigub]. Antikvar. https://antikvar.ua/ocherkzhizni-i-tvorchestva-hudozhnika-iv/ [in Russian]. 


\title{
ТВОРЧІСТЬ МИКОЛИ ЦІВЧИНСЬКОГО: ВНЕСОК ШКОЛИ М. БОЙЧУКА В МИСТЕЦТВО КАЗАХСТАНСЬКОГО ГОБЕЛЕНА
}

\author{
Сураганов Сергалі Кабдрахманович ${ }^{1 a}$, Сураганова Зубайда Кабіївна ${ }^{2 b}$
}

${ }^{1}$ Старший викладач,

ORCID: 0000-0003-0319-8115, sersuraganov@mail.ru,

${ }^{2}$ Кандидат історичних наук,

ORCID: 0000-0001-9893-6461, suraganova_zk@mail.ru,

${ }^{a}$ Казахський агротехнічний університет імені С. Сейфулліна,

Нур-Султан, Казахстан,

${ }^{b}$ Державний історико-культурний музей-заповідник «Бозок»

Міністерства культури і спорту Республіки Казахстан,

Нур-Султан, Казахстан

Мета дослідження - ввести в науковий обіг творчі досягнення М. В. Цівчинського в контексті становлення художньої школи українського авангарду Михайла Бойчука. Завданнями дослідження стали: визначення витоків становлення творчості художника-монументаліста, майстра декоративно-прикладного мистецтва М. В. Цівчинського, його внеску у становлення історії казахстанського професійного мистецтва гобелена. У його творчості відбивається проникливість і глибоке розуміння значення самобутності традиційної культури народу, монументалізм, притаманні школі М. Бойчука. Один із небагатьох бойчукістів, які залишилися в живих і яких доля розкидала по всьому світу, М. В. Цівчинський не тільки розвинув різнобічні навички, художні мову і традицію школи бойчукістів, а став однією з найяскравіших постатей у казахстанському декоративно-прикладному мистецтві. Життєвий шлях і творчість М. В. Цівчинського повною мірою відображають найважливіші і трагічні сторінки розвитку країни, якої вже немає на карті. В дослідженні використано біографічний, джерелознавчий та історичний методи. Методологічною новацією $є$ використання біографічного методу поряд з історичним у рамках «нової компаративної історії» як ефективного інструменту при вивченні художньої спадщини Казахстану і України в радянську епоху. Наукова новизна дослідження визначається введенням нових відомостей про художника, творчість якого лише згадувалася в контексті діяльності школи бойчукістів, значну частину послідовників якої було знищено в роки червоного терору. Висновки. Творчість М. В. Цівчинського розглядається в контексті діяльності художньої школи М. Бойчука, де відбулося його становлення як майстра декоративноприкладного мистецтва. У 1930-ті рр. в Казахстані М. В. Цівчинський продовжив традиції бойчукістів, став засновником першої килимової артілі, що стала посправжньому знаковим явищем в історії формування професійного декоративноприкладного мистецтва в республіці.

Ключові слова: бойчукісти; гобелен; декоративно-прикладне мистецтво; кооперативно-промислова артіль «Ковровщица»; Казахстан; Микола Цівчинський; Україна; школа Михайла Бойчука; ВМДПНМ 


\title{
ТВОРЧЕСТВО НИКОЛАЯ ЦИВЧИНСКОГО: ВКЛАД ШКОЛЫ М. БОЙЧУКА В ИСКУССТВО КАЗАХСТАНСКОГО ГОБЕЛЕНА
}

\author{
Сураганов Сергали Кабдрахманович ${ }^{1 a}$, Сураганова Зубайда Кабиевна ${ }^{2 b}$ \\ ${ }^{1}$ Старший преподаватель, \\ ORCID:0000-0003-0319-8115, sersuraganov@mail.ru, \\ ${ }^{2}$ Кандидат исторических наук, \\ ORCID:0000-0001-9893-6461,suraganova_zk@mail.ru, \\ ${ }^{a}$ Казахский агротехнический университет имени С. Сейфуллина, \\ Нур-Султан, Казахстан, \\ ${ }^{b}$ Государственный историко-культурный музей-заповедник «Бозок» \\ Министерства культуры и спорта Республики Казахстан, \\ Нур-Султан, Казахстан
}

Цель исследования - ввести в научный оборот творческие достижения Н. В.Цивчинского в контексте становления художественной школы украинского авангарда Михаила Бойчука. Задачами исследования стали: определение истоков становления творчества художника-монументалиста, мастера декоративно-прикладного искусства Н. В. Цивчинского, его вклада в становление истории казахстанского профессионального искусства гобелена. В его творчестве отражается проникновенность и глубокое понимание значения самобытности традиционной культуры народа, монументализм, присущие школе М. Бойчука. Один из немногих оставшихся в живых бойчукистов, которых судьба разбросала по всему миру, Н. В. Цивчинский не только развил привитые ему разносторонние навыки, художественные язык и традицию школы бойчукистов, но стал одной из ярких фигур в казахстанском декоративно-прикладном искусстве. Жизненный путь и творчество Н. В. Цивчинского в полной мере отражают самые важные и трагические страницы развития страны, которой уже нет на карте. В качестве методов исследования использованы биографический, источниковедческий и исторический. Методологической новацией исследования является использование биографического метода наряду с историческим в рамках «новой компаративной истории» как эффективного инструмента при изучении художественного наследия Казахстана и Украины в советскую эпоху. Научная новизна исследования определяется введением новых сведений о художнике, творчество которого лишь упоминалось в контексте деятельности школы бойчукистов, значительная часть последователей которой была уничтожена в годы красного террора. Выводы. Творчество Н. В. Цивчинского рассматривается в контексте деятельности художественной школы М. Бойчука, где произошло его становление как мастера декоративно-прикладного искусства. В 1930-е гг. в Казахстане Н.В. Цивчинский продолжил традиции бойчукистов, стал основателем первой ковровой артели, ставшей по-настоящему знаковым явлением в истории формирования профессионального декоративно-прикладного искусства в республике.

Ключевые слова: бойчукисты; гобелен; декоративно-прикладное искусство; кооперативно-промысловая артель «Ковровщица»; Казахстан; Николай Цивчинский; Украина; школа Михаила Бойчука; ВМДПни 